\title{
Introduction and Bibliography
}

Hampton Carson first came to Hawaii in June 1963 at the urging of Elmo Hardy and Wilson Stone. That year saw the first major gathering in Honolulu of scientists from many specialties in the interdisciplinary and cooperative pattern that has proved so productive in the study of Hawaiian Drosophila on "the Project" (Spieth 1980). Carson came with Harrison Stalker from Washington University in St. Louis. Together (following Dobzhansky), they had developed a powerful method of population studies based on detailed examination of the distribution of inversions in the polytene chromosomes of Drosophila robusta and other species of the mesic forests of the central and eastern United States.

Carson's cytological approach can be traced to the influence of McClung, and especially of Metz, during his graduate studies at the University of Pennsylvania in the late 1930s and early 1940s (Carson 1980). These studies combined with his interests in natural history to produce a wide-ranging, synthetic approach to the study of biology, which is reflected in the considerable diversity of topics in the 237 published papers listed below.

In the breadth of his curiosity and the flexibility of his intellect, Carson himself represents almost an apotheosis of the pattern that studies of Hawaiian Drosophila have followed. These studies have included essential contributions from systematics and taxonomy, ecology, physiology, botany, geology, cytology, genetics, behavior, and biochemistry. Carson has made major contributions in each of these areas either by his own work or by bringing to light the relevant work of others. He has moved from one of these areas to another as the need for new approaches arose, and generously encouraged the participation of colleagues with new and appropriate skills, a few of whom are represented in the papers that follow. Future research in evolutionary biology would do well to continue with such flexible and open approaches.

\section{LITERATURE CITED}

CARson, H. L. 1980. Hypotheses that blur and grow. Pages 383-384 in E. Mayr and W. B. Provine, eds. The evolutionary synthesis: Perspectives on the unification of biology. Harvard Univ. Press, Cambridge, Mass.

SPIETH, H. T. 1980. Hawaiian Drosophila Project. Proc., Hawaiian Entomol. Soc. 23(2):275-291.

Bibliography of Hampton Lawrence Carson 1934-1986

1. Carson, H. L. 1934. Labrador quarry. General Mag. 37(1):97-104.

2. CARson, H. L. 1935. Use of medicinal herbs among the Labrador Eskimo. General Mag. 37(4):436-439.

3. Carson, H. L. 1940. Red crossbill in North Carolina in summer. Auk 57: 421.

4. Carson, H. L. 1941. Linkage, interference and semilethals in the white group of Habrobracon. Amer. Nat. 75:608614.

5. Carson, H. L. 1943. Cytological analysis of natural populations of Sciara impatiens. Genetics 28:71-72 (abstract).

6. Carson, H. L. 1944. An analysis of natural chromosome variability in Sciara impatiens Johannsen. J. Morph. 75(1): 11-59.

7. Carson, H. L. 1945a. A comparative study of the apical cell of the insect testis. J. Morph. 77(2): 141-161.

8. Carson, H. L. $1945 b$. Delayed fertilization in a captive indigo snake, with notes on feeding and shedding. Copeia 1945(4): 222-225.

9. Carson, H. L. 1946a. The selective elimination of inversion dicentric chromatids during meiosis in the eggs of Sciara impatiens. Genetics 31:95-113. 
10. Carson, H. L., and H. D. Stalker. 1946b. Chromosome studies on Drosophila robusta. Genetics 31(2):213 (abstract).

11. Stalker, H. D., and H. L. Carson. 1946c. Geographical variation in the morphology of Drosophila robusta. Genetics 31(2): 231 (abstract).

12. Carson, H. L., and H. D. Stalker. $1947 a$. A seasonal study of gene arrangement frequencies and morphology in Drosophila robusta. Genetics 32(1):81 (abstract).

13. Carson, H. L., and H. D. Stalker. $1947 b$. Gene arrangements in natural populations of Drosophila robusta Sturtevant. Evolution 1(3): 113-133.

14. Stalker, H. D., and H. L. Carson. $1947 c$. Morphological variation in natural populations of Drosophila robusta Sturtevant. Evolution 1(4):237-248.

15. Carson, H. L., and H. D. Stalker. 1948a. Reproductive diapause in Drosophila robusta. Proc. Nat. Acad. Sci. 34: 124-129.

16. Carson, H. L., and H. D. Stalker. 1948b. An altitudinal transect of gene arrangement frequencies in Drosophila robusta. Genetics 33:100 (abstract).

17. Stalker, H. D., and H. L. Carson. $1948 c$. Seasonal changes in gene arrangement frequencies and morphology of Drosophila robusta. Genetics 33: 629-630 (abstract).

18. Stalker, H. D., and H. L. Carson. 1948d. An altitudinal transect of Drosophila robusta Sturtevant. Evolution 2: 295-305.

19. Stalker, H. D., and H. L. Carson. 1949a. Seasonal variation in the morphology of Drosophila robusta Sturtevant. Evolution 3:330-343.

20. Carson, H. L., and H. D. Stalker. $1949 b$. Seasonal variation in gene arrangement frequencies over a threeyear period in Drosophila robusta Sturtevant. Evolution 3:322-329.

21. Carson, H. L., and H. D. Stalker. 1950. Natural breeding sites for Drosophila robusta. Genetics 35:100 (abstract).

22. Carson, H. L., and H. D. Stalker. 1951a. Natural breeding sites for some wild species of Drosophila in the eastern United States. Ecology 32:317-330.

23. CARSON, H. L. $1951 b$. Breeding sites of Drosophila pseudoobscura and Drosophila persimilis in the transition zone of the Sierra Nevada. Evolution 5:91-96.

24. Carson, H. L. 1951c. Interfertile sympatric sibling species within D. bocainensis Pavan and da Cunha 1947. Dros. Inf. Serv. 25: 103-104.

25. Carson, H. L., and W. C. Blight. 1952a. Sex chromosome polymorphism in a population of Drosophila americana. Genetics 37:572 (abstract).

26. Carson, H. L. 1952b. Contrasting types of population structure in Drosophila. Amer. Nat. 86:239-248.

27. Carson, H. L. 1952c. A new case of cryptic species in Drosophila. Science 116:518 (abstract).

28. CARSON, H. L. 1953a. The effects of inversions on crossing over in Drosophila robusta. Genetics 38:168-186.

29. Carson, H. L. 1953b. Evolution in the genus Drosophila. J. T. Patterson and W. S. Stone, 1952. (Review) Amer. Nat. 87:271-272.

30. Levitan, M., H. L. Carson, and H. D. STALKER. 1954a. Triads of overlapping inversions in Drosophila robusta. Amer. Nat. 88: 113-114.

31. CARSON, H. L. 1954b. Interfertile sibling species in the willistoni group of Drosophila. Evolution 8: 148-165.

32. Carson, H. L. 1954c. Hybridization experiments with two sympatric sibling species of the willistoni group of Drosophila. Caryologia 6(suppl.):653 (abstract).

33. CARson, H. L. 1955a. Variation in genetic recombination in natural populations. J. Cell. Comp. Physiol. 45(suppl. 2): 221-236.

34. CARSON, H. L. 1955b. The genetic characteristics of marginal populations of Drosophila. Cold Spring Harbor Symp. Quant. Biol. 20:276-287.

35. Dorsey, C. K., and H. L. Carson. $1956 a$. Selective response of wild Drosophilidae to natural and artificial attrahents. Ann. Entomol. Soc. Amer. 49: 177-181. 
36. Carson, H. L. 1956b. Marginal homozygosity for gene arrangement in Drosophila robusta. Science 123:630-631.

37. Carson, H. L., E. P. KnapP, and H. J. PHAFF. 1956c. Studies on the ecology of Drosophila in the Yosemite region of California. III. The yeast flora of the natural breeding sites of some species of Drosophila. Ecology 37(3):538-544.

38. Dobzhansky, T., D. M. CoOPeR, H. J. PhafF, E. P. KNAPP, and H. L. CARSON. 1956d. Studies on the ecology of Drosophila in the Yosemite region of California. IV. Differential attraction of species of Drosophila to different species of yeasts. Ecology 37(3): 544-550.

39. CARSON, H. L. 1956e. Response of Drosophila robusta to selection for motility. Genetics 41:636-637 (abstract).

40. Carson, H. L. 1956f. A female-producing strain of $D$. borealis Patterson. Dros. Inf. Serv. 30: 109-110.

41. Carson, H. L., M. R. Wheeler, and W. B. HeED. 1957a. A parthenogenetic strain of Drosophila mangabeirai Malogolowkin. Univ. Texas Pub. 5721: 115-122.

42. Carson, H. L. 1957b. The species as a field for gene recombination. Pages 23-38 in E. Mayr, ed. The species problem. Amer. Assoc. Adv. Sci. Pub. 50: 23-38. Washington, D.C.

43. Carson, H. L. 1957c. Parrot-watching. Bull. St. Louis Aud. Soc. 26:1-3.

44. Carson, H. L. 1957d. Production of biomass as a measure of fitness of experimental populations of Drosophila. Genetics 42:363-364.

45. Wolfson, M., H. D. Stalker, and H. L. CARSON. 1957e. A serious parasite of laboratory Drosophila. Dros. Inf. Serv. 31:170.

46. Carson, H. L. 1958a. The population genetics of Drosophila robusta. Adv. Genetics 9:1-40.

47. CARSON, H. L. 1958b. Increases of fitness in experimental populations following introduction of one haploid set of autosomes. Proc. 10th Internat. Congr. Genetics. II. 44-45.

48. Carson, H. L. 1958c. Response to selection under different conditions of recombination in Drosophila. Cold Spring Harbor Symp. Quant. Biol. 23: 291-306.

49. Carson, H. L. 1958d. Increase in fitness in experimental populations resulting from heterosis. Proc. Nat. Acad. Sci. 44:1136-1141.

50. Susman, M., and H. L. Carson. $1958 e$. Development of balanced polymorphism in laboratory populations of Drosophila melanogaster. Amer. Nat. 92:359364.

51. Carson, H. L. 1958f. A study of experimental populations of Drosophila. Proc. Entomol. Soc. Amer. No. Cent. Br. 13: 22.

52. Murdy, W. H., and H. L. Carson. 1959a. Parthenogenesis in Drosophila mangebeirai. Amer. Nat. 93:355-363.

53. CaRson, H. L. 1959b. Effect of irradiation on artificial populations under strong natural selection. Rec. Genet. Soc. Amer. 28:63 (abstract).

54. Carson, H. L. 1959c. Genetic conditions which promote or retard the formation of species. Cold Spring Harbor Symp. Quant. Biol. 24:87-105.

55. Carson, H. L. 1960. Survival of newly induced chromosome aberrations in experimental populations of Drosophila melanogaster. Genetics 45:980-981 (abstract).

56. Carson, H. L. 1961a. Variation. Pages 1047-1049 in The encyclopedia of the biological sciences. Reinhold, New York.

57. Carson, H. L. 1961b. Rare parthenogenesis in Drosophila robusta. Amer. Nat. 95:81-86.

58. CaRson, H. L. 1961c. Relative fitness of genetically open and closed experimental populations of Drosophila robusta. Genetics 46:553-567.

59. Carson, H. L. 1961d. Heterosis and fitness in experimental populations of Drosophila melanogaster. Evolution $15: 456-509$.

60. Heed, W. B., H. L. Carson, and M. S. CARSON. 1961e. A list of flowers utilized by drosophilids in the Bogotá region of Colombia. Dros. Inf. Serv. 34:84-85.

61. Carson, H. L. 1962a. Fixed hetero- 
zygosity in a parthenogenetic species of Drosophila. Univ. Texas Pub. 6205: 55-62.

62. Carson, H. L. $1962 b$. Selection for parthenogenesis in Drosophila mercatorum. Genetics 47:946.

63. CARson, H. L. $1963 a$. Silent spring, by Rachel L. Carson, a review. Coll. Univ. 38:294-296.

64. Carson, H. L. 1963b. Transitory increase in genetic load in irradiated laboratory populations of Drosophila melanogaster. Proc. 11th Internat. Congr. Genetics. 1:74.

65. Stalker, H. D., and H. L. Carson. $1963 c$. A very serious parasite of laboratory Drosophila. 2nd Rept. Dros. Inf. Serv. 38:96.

66. CARSON, H. L. 1963d. Heredity and human life. Columbia Univ. Press, New York.

67. Carson, H. L. 1963e. Humanism and the new biology. Wash. Univ. Mag. 34: 7-9.

68. Carson, H. L. $1963 f$. Introduction to The origin of species, by Charles Darwin. Washington Square Press, New York. Pp. xi-xviii.

69. Carson, H. L. 1964a. Population size and genetic load in irradiated populations of Drosophila melanogaster. Genetics 49:521-528.

70. Carson, H. L., and W. B. HeEd. $1964 b$. Structural homozygosity in marginal populations of nearctic and neotropical species of Drosophila in Florida. Proc. Nat. Acad. Sci. U.S. 52:427-430.

71. Carson, H. L., M. J. D. White, and J. CHENEY. 1964c. Chromosomal races in the Australian grasshopper Moraba viatica in a zone of geographic overlap. Evolution 18:417-429.

72. CARSON, H. L. 1965a. Eugenics: Hereditarian attitudes in American thought, by Mark H. Haller. A review. Amer. J. Sociol. 70:505.

73. Carson, H. L., and M. Wasserman. 1965b. A widespread chromosomal polymorphism in a widespread species, Drosophila buzzatii. Amer. Nat. 99: 111-115.
74. Carson, H. L. 1965c. Chromosomal morphism in geographically widespread species of Drosophila. Pages 503-531 in The genetics of colonizing species. Academic Press, New York.

75. CARson, H. L. 1966. Chromosomal races of Drosophila crucigera from the islands of Oahu and Kauai, State of Hawaii. Univ. Texas Pub. 6615:405412.

76. CARSON, H. L. 1967a. Inbreeding and gene fixation in natural populations. Pages 281-308 in R. Alexander Brink, ed. Heritage from Mendel. Univ. Wisc. Press, Madison.

77. CARSON, H. L. $1967 b$. Selection for parthenogenesis in Drosophila mercatorum. Genetics 55:157-171.

78. CARSON, H. L. 1967c. Permanent heterozygosity. Pages 143-168 in T. Dobzhansky, M. K. Hecht, and W. C. Steere, eds. Evolutionary biology. Vol. 1. AppletonCentury-Crofts, New York.

79. Carson, H. L., F. E. Clayton, and H. D. Stalker. 1967d. Karyotypic stability and speciation in Hawaiian Drosophila. Proc. Nat. Acad. Sci. U.S. 57: 1280-1285.

80. CARSON, H. L. 1967e. The association between Drosophila carcinophila Wheeler and its host, the land crab Gecarcinus ruricola (L.) Amer. Midl. Nat. 78:324343.

81. Carson, H. L. 1967f. Chromosomal polymorphism in altitudinal races of Drosophila. Proc. Jap. Soc. Syst. Zool. 3:10-16.

82. Carson, H. L. 1967g. Genetics and evolution of Hawaiian Drosophilidae: Preliminary report of collections made in Kipahulu Valley, Maui. Scientific report of the Kipahulu Valley Expedition. Richard E. Warner, ed. Nat. Conserv. 87-91.

83. Carson, H. L., and M. R. Wheeler. 1968a. Drosophila endobranchia, a new Drosophilid associated with land crabs in the West Indies. Ann. Entomol. Soc. Amer. 61:675-678.

84. Carson, H. L. 1968b. Parallel inversion polymorphisms in different species 
of Hawaiian Drosophila. Proc. 12th Internat. Congr. Genetics 1:321.

85. Carson, H. L., and H. D. Stalker. $1968 c$ Polytene chromosome relationships in Hawaiian species of Drosophila. I. The D. grimshawi subgroup. Univ. Texas Pub. 6818:335-354.

86. Carson, H. L., and H. D. Stalker. $1968 d$. Polytene chromosome relationships in Hawaiian species of Drosophila. II. The D. planitibia subgroup. Univ. Texas Pub. 6818:355-365.

87. Carson, H. L., and H. D. Stalker. 1968e. Polytene chromosome relationships in Hawaiian species of Drosophila. III. The $D$. adiastola and $D$. punalua subgroups. Univ. Texas Pub. 6818: 367-380.

88. Carson, H. L. $1968 f$. The population flush and its genetic consequences. Pages 123-137 in R. C. Lewontin, ed. Population biology and evolution. Syracuse Univ. Press, Syracuse, N.Y.

89. Carson, H. L. 1969a. Parallel polymorphisms in different species of Hawaiian Drosophila. Amer. Nat. 103:323-329.

90. Carson, H. L., and J. E. Sato. $1969 b$. Microevolution within three species of Hawaiian Drosophila. Evolution 23: 493-501.

91. CARSON, H. L. 1969c. Maintenance of lethal and detrimental genes in natural populations. Introduction and synthesis by the Chairman. Symp. 15, 12th Internat. Congr. Genetics. Japan. J. Genetics 44, Suppl. 1:225-227.

92. Carson, H. L., and H. D. Stalker. $1969 d$. Polytene chromosome relationships in Hawaiian species of Drosophila. IV. The D. primaeva subgroup. Univ. Texas Pub. 6918:85-94.

93. Carson, H. L., I. Y. WeI, and J. A. NIEDERKORN, JR. 1969e. Isogenicity in parthenogenetic strains of Drosophila mercatorum. Genetics 63:619-628.

94. Carson, H. L. $1969 f$. Drosophilidae of Hawaii. Ann. Missouri Bot. Gard. 56: 417-418.

95. Carson, H. L., D. E. Hardy, H. T. SpIETH, and W. S. Stone. 1970a. The evolutionary biology of the Hawaiian
Drosophilidae. Pages 437-543 in M. K. Hecht and W. C. Steere, eds. Essays in evolution and genetics in honor of Theodosius Dobzhansky. AppletonCentury-Crofts, New York.

96. Carson, H. L. 1970b. Chromosome tracers of the origin of species. Science 168:1414-1418.

97. Carson, H. L. 1970c. Chromosomal tracers of founder events. Biotropica 2:3-6.

98. Carson, H. L. 1971a. Polytene chromosome relationships in Hawaiian species of Drosophila. V. Additions to the chromosomal phylogeny of the picturewinged species. Univ. Texas Pub. 7103: 183-191.

99. Carson, H. L. 1971b. The ecology of Drosophila breeding sites. Univ. Hawaii, Honolulu. Harold L. Lyon Arboretum Lecture No. 2:1-27.

100. Carson, H. L. 1971c. Speciation and the founder principle. Stadler Genetics Symp. 3:51-70.

101. Carson, H. L., and S. H. Snyder. 1972a. Screening by parthenogenesis for induced mutations in Drosophila mercatorum. Egypt. J. Gen. Cytol. 1: 256-261.

102. CARSON, H. L. $1972 b$. Evolutionary biology: Its value to society. Bioscience 22 : 349-352.

103. Carson, H. L. 1972 . Ancient chromosomal polymorphism and its use in phylogeny. Abstr. 14th Internat. Congr. Entomol. Canberra, Austral., p. 50.

104. Clayton, F. E., H. L. Carson, and J. E. Sato. 1972d. Polytene chromosome relationships in Hawaiian species of Drosophila. VI. Supplementary data on metaphases and gene sequences. Univ. Texas Pub. 7213:163-177.

105. CARsOn, H. L. 1972e. Microevolution. A review of ecological genetics and evolution. Essays in honour of E. B. Ford. Robert Creed, ed., Blackwell, Oxford and Appleton-Century-Crofts, New York, 1971. Science 178:855-856.

106. Carson, H. L. 1973a. Ancient chromosomal polymorphism in Hawaiian Drosophila. Nature 241:200-202. 
107. Carson, H. L. $1973 b$. The genetic system in parthenogenetic strains of Drosophila mercatorum. Proc. Nat. Acad. Sci. U.S. 70:1772-1774.

108. Yoon, J. S., and H. L. Carson. 1973c. Codification of polytene chromosome designations for Hawaiian Drosophilidae. Genetics 74:s303-s304.

109. Carson, H. L., and M. R. Wheeler. 1973d. A new crab fly from Christmas Island, Indian Ocean (Diptera: Drosophilidae). Pac. Insects 15: 199-208.

110. Kaneshiro, K. Y., H. L. Carson, F. E. Clayton, and W. B. Heed. 1973e. Niche separation in a pair of homosequential Drosophila species from the island of Hawaii. Amer. Nat. 107: 766-774.

111. Carson, H. L., D. E. Hardy, L. H. THROCKMORTON, M. WASSERMAN, and M. R. WheELER. 1973f. Drosophila carinata Grimshaw, 1901 (Insecta, Diptera): Proposed suppression under the plenary powers in order to preserve Drosophila mercatorum Patterson and Wheeler, 1942 Z. N. (S) 2035. Bull. Zool. Nomencl. 30(2): 112-117.

112. CaRson, H. L. $1973 g$. Reorganization of the gene pool during speciation. Pages 274-280 in Newton E. Morton, ed. Genetic structure of populations. Population genetics monographs. Vol. III. Univ. Press of Hawaii, Honolulu.

113. IKedA, H., and H. L. CARson. 1973h. Selection for mating reluctance in females of a diploid parthenogenetic strain of Drosophila mercatorum. Genetics 75:541-555.

114. Carson, H. L., W. W. M. Steiner, and W. E. Johnson. 1973i. Molecular differentiation in D. grimshawi. Dros. Inf. Serv. 50:100-101.

115. CARson, H. L. 1974a. The Biston affair. A review of the evolution of melanism. B. Kettlewell. Clarendon (Oxford Univ. Press, New York, 1973). Science 183: 67.

116. Ahearn, J. N., H. L. Carson, T. DOBZHANSKY, and K. Y. KANESHIRO. 1974b. Ethological isolation among three species of the planitibia subgroup of Hawaiian Drosophila. Proc. Nat. Acad. Sci. U.S. 71:901-903.

117. CARSON, H. L. 1974c. Human genetics. Pages 996-1010 in Encyclopaedia Britannica macropaedia. Vol. 7. Encyl. Brit. Inc., Helen Hemingway Benton, Publ., Chicago.

118. Carson, H. L. 1974d. Patterns of speciation in Hawaiian Drosophila inferred from ancient chromosomal polymorphism. Pages 81-93 in M. J. D. White, ed. Genetic mechanisms of speciation in insects. Australia and New Zealand Book Co., Sydney.

119. Carson, H. L. 1974e. Natural history of islands. A review of island biology. S. Carlquist and M. J. Cole. (Columbia Univ. Press, New York, 1974). Science 186:252-253.

120. Carson, H. L. $1974 f$. Three flies and three islands: Parallel evolution in Drosophila. Proc. Nat. Acad. Sci. U.S. 71: 3517-3521.

121. Carson, H. L., and W. W. M. Steiner. $1974 \mathrm{~g}$. Genetic structure and variability in two species of endemic Hawaiian Drosophila. U.S./I.B.P. Island Ecosystems IRP. Techn. Rept. No. 50:iv and $66 \mathrm{pp}$.

122. CARSON, H. L. 1975a. The genetics of speciation at the diploid level. Amer. Nat. 109:82-92.

123. Carson, H. L., and W. E. Johnson. $1975 b$. Genetic variation in Hawaiian Drosophila I. Chromosome and allozyme polymorphism in $D$. setosimentum and $D$. ochrobasis from the island of Hawai'i. Evolution 29:11-23.

124. Johnson, W. E., H. L. Carson, K. Y. Kaneshiro, W. W. M. Steiner, and M. M. COOPER. 1975c. Genetic variation in Hawaiian Drosophila II. Allozymic differentiation in the $D$. planitibia subgroup. Pages 563-584 in C. L. Markert, ed. Isozymes IV. Genetics and evolution. Academic Press, New York.

125. Carson, H. L., W. E. Johnson, P. S. NAIR, and F. M. SenE. 1975d. Genetic similarities based on allozymic and chromosomal data. Genetics 80:s19. 
126. Craddock, E. M., and H. L. Carson. 1975e. Chromosome variability in an endemic Hawaiian Drosophila species. Genetics 80:s23.

127. Johnson, W. E., and H. L. Carson. 1975f. Allozymic variation in Drosophila silvestris. Genetics 80:s46.

128. NaIr, P. S., F. M. Sene, and H. L. CARSON. 1975g. Regulatory influence on isozyme expression in Drosophila. Genetics 80:s60.

129. Carson, H. L., P. S. Nair, and F. M. SENE. 1975h. Drosophila hybrids in nature: Proof of gene exchange between sympatric species. Science 189:806807.

130. Carson, H. L., W. E. Johnson, P. S. NAIR, and F. M. SENE. 1975i. Genetic variation in Hawaiian Drosophila III. Allozymic and chromosomal similarity in two Drosophila species. Proc. Nat. Acad. Sci. U.S. 12:4521-4525.

131. Carson, H. L. 1976a. Inference of the time of origin of some Drosophila species. Nature 259:395.

132. Templeton, A. R., H. L. Carson, and C. F. Sing. 1976b. The population genetics of parthenogenetic strains of Drosophila mercatorum II. The capacity for parthenogenesis in a natural, bisexual population. Genetics 82:527-542.

133. Sene, F. M., and H. L., Carson. 1976c. Close allozymic similarity within and between two sympatric species of Hawaiian Drosophila. Genetics 83: s69-70.

134. Carson, H. L. 1976d. Genetic differences between newly formed species. Bioscience 26:700-701.

135. Carson, H. L. 1976e. The unit of genetic change in adaptation and speciation. Ann. Missouri Bot. Gard. 63:210-233.

136. Carson, H. L., and K. Y. Kaneshiro. 1976f. Drosophila of Hawaii: Systematics and ecological genetics. Ann. Rev. Ecol. Syst. 7:311-346.

137. CARson, H. L. 1976g. Ecology of rare Drosophila species in Hawaii Volcanoes National Park. Pages 39-45 in Proc. 1st Conf. Nat. Sci. Hawai'i Volcanoes National Park. Cooperative National Park Resources Studies Unit.
Dept. of Botany, Univ. of Hawaii, Honolulu.

138. Carson, H. L., L. T. Teramoto, and A. R. Templeton. 1977a. Behavioral differences among isogenic strains of Drosophila mercatorum. Behavior Genetics 7:189-197.

139. Sene, F. M., and H. L. Carson. $1977 b$. Genetic variation in Hawaiian Drosophila IV. Allozymic similarity between $D$. silvestris and $D$. heteroneura from the island of Hawaii. Genetics 86:187197.

140. Nair, P. S., H. L. Carson, and F. M. SENE. 1977c. Isozyme polymorphism due to regulatory influence. Amer. Nat. 111:789-791.

141. Carson, H. L. 1977d. Introductions to a pivotal subject. Review of evolution, by Theodosius Dobzhansky, et al., and Organismic evolution, by Verne Grant. Science 197: 1272-1273.

142. Fontdevila, A., and H. L. Carson. 1978a. Spatial distribution and dispersal in a population of Drosophila. Amer. Nat. 112:365-380.

143. Carson, H. L. 1978b. Chromosomes and species formation. Evolution 32: 925-927.

144. Carson, H. L. 1978c. Speciation and sexual selection in Hawaiian Drosophila. Pages 93-107 in P. F. Brussard, ed. Ecological genetics: The interface. Springer-Verlag, New York.

145. Carson, H. L. 1978d. Hawai‘i IBP synthesis: 6 . Genetic variation and population structure in island species. Page 41 in Proc. 2nd Conf. Nat. Sci. Hawai'i Volcanoes National Park. Cooperative National Park Resources Studies Unit. Dept. of Botany, Univ. of Hawaii, Honolulu (abstract).

146. Carson, H. L. 1978e. Genetic distance, sexual selection, and speciation. Pages 84-87 in H. I. Oka and O. Kitagawa, eds. Dynamics of speciation in plants and animals. U.S.-Japan Cooperative Science Program. Japan Soc. Prom. Science, Tokyo.

147. Carson, H. L., and P. J. Bryant. 1979a. Genetic variation in Hawaiian 
Drosophila VI. Change in a secondary sexual character as evidence of incipient speciation in Drosophila. Proc. Nat. Acad. Sci. U.S. 76:1929-1932.

148. Bryant, P. J., and H. L. Carson. $1979 b$. Genetics of an interspecific difference in a secondary sexual character in Hawaiian Drosophila. Genetics 91: s15-s16.

149. CARson, H. L. 1979c. Local variation in a secondary sexual character in Drosophila. Genetics 91 : s18.

150. Dickinson, W. J., and H. L. Carson. $1979 d$. Regulation of the tissue specificity of an enzyme by a cis-acting genetic element: Evidence from interspecific Drosophila hybrids. Proc. Nat. Acad. Sci. U.S. 76:4559-4562.

151. Carson, H. L., and T. Okada. 1980a. Drosophilidae associated with flowers in Papua New Guinea. I. Colocasia esculenta. Kontyû 48: 15-29.

152. Carson, H. L., and A. T. Ohta. $1980 b$. Origin of the genetic basis of colonizing ability. Abstr. 2nd Internat. Congr. Syst. Evol. Biol. Vancouver: Univ. of British Columbia, p. 39.

153. Carson, H. L. 1980c. Evolution of studies on Hawaiian Drosophilidae. Abstr. 2nd Internat. Congr. Syst. Evol. Biol. Vancouver: Univ. of British Columbia, p. 110.

154. Carson, H. L., and T. Okada. 1980d. The ecology and evolution of some flower-breeding Drosophilidae of New Guinea. Abstr. 16th Internat. Congr. Entomol. Kyoto, Japan, p. 7.

155. Carson, H. L., and L. T. Teramoto. 1980 e. Differences in copulatory success among laboratory males of Drosophila silvestris. Genetics 94:s14.

156. Carson, H. L. $1980 f$. Homosequential species of Hawaiian Drosophila. Proc. 7th Internat. Chromosome Conf. Oxford, England, p. 18 (abstract).

157. Carson, H. L. 1980g. Cytogenetics and the neo-Darwinian synthesis. Pages 86-95 in E. Mayr and W. B. Provine, eds. The evolutionary synthesis. Harvard Univ. Press, Cambridge, Mass.

158. Carson, H. L. $1980 h$. Hypotheses that blur and grow. Pages 383-384 in E. Mayr and W. B. Provine, eds. The evolutionary synthesis. Harvard Univ. Press, Cambridge, Mass.

159. CARson, H. L. 1980i. Variation among males of Drosophila silvestris in the Olaa tract, Hawaii Volcanoes National Park. Page 51 in Proc. 3rd Conf. Nat. Sci. Hawaii Volcanoes National Park. Cooperative National Park Resources Studies Unit. Dept. of Botany, Univ. of Hawaii, Honolulu (abstract).

160. Carson, H. L. $1980 j$. A provocative view of the evolutionary process. In Richard Goldschmidt, Controversial geneticist and creative biologist. Ed. L. K. Piternick. Birkhauser, Basel. Experientia Suppl. 35:24-26.

161. OKadA, T., and H. L. CARson. 1980k. Drosophilidae associated with flowers in Papua New Guinea II. Alocasia (Araceae). Pac. Insects 22:217-236.

162. Carson, H. L. 1980l. Chromosomes and evolution in some relatives of Drosophila grimshawi from Hawaii. Symp. R. Entomol. Soc. London 10: 195-205.

163. CARSON, H. L. 1981a. Macroevolution conference: A letter to the editor. Science $211: 773$.

164. Carson, H. L. 1981b. Genetics in Russia. A review of animal genetics and evolution, N. N. Vorontsov and J. M. van Brink, eds. The Hague: Junk. 384 pp., 1978. Science 211:932-933.

165. CARSON, H. L. 1981c. Chromosomal tracing of evolution in a phylad of species related to Drosophila hawaiiensis. Pages 286-297 in W. R. Atchley and D. S. Woodruff, eds. Evolution and speciation. Cambridge Univ. Press, Cambridge.

166. Carson, H. L. 1981d. Age of chromosomal polymorphism in Drosophila silvestris. Genetics 97:s17.

167. Sene, F. M., J. M. Amabis, H. L. Carson, and T. H. F. S. Cyrino. 1981e. Chromosome polymorphism in Drosophila mercatorum pararepleta in South America. Rev. Bras. Genet. 4:1-10.

168. Carson, H. L. $1981 f$. Homosequential species of Hawaiian Drosophila. Pages 150-164 in M. D. Bennett, M. Bobrow, 
and G. Hewitt, eds. Chromosomes today. Vol. 7. Allen and Unwin, London.

169. Mueller-Dombois, D., K. W. Bridges, and H. L. CARson, eds. $1981 \mathrm{~g}$. Island ecosystems: Biological organization in selected Hawaiian communities. Hutchinson-Ross, Stroudsburg, Pa. 583 pp.

170. Carson, H. L. $1981 h$. Genetic variation within island species. Introduction. Pages 431-437 in D. Mueller-Dombois, K. W. Bridges, and H. L. Carson, eds. Island ecosystems: Biological organization in selected Hawaiian communities. Hutchinson-Ross, Stroudsburg, $\mathrm{Pa}$.

171. SpIESS, E. B., and H. L. CARson. $1981 i$. Sexual selection in Drosophila silvestris of Hawai'i. Proc. Nat. Acad. Sci. U.S. 78:3088-3092.

172. Stuart, W. D., J. G. Bishop, H. L. Carson, and M. B. Frank. 1981j. Location of the $18 / 28 \mathrm{~S}$ ribosomal RNA genes in two Hawaiian Drosophila species by monoclonal immunological identification of RNA-DNA hybrids in situ. Proc. Nat. Acad. Sci. U.S. 78: 3751-3754.

173. CARSON, H. L. $1981 k$. Genetic variation within and between endemic Hawaiian species of Drosophila. Pages 451-455 in D. Muller-Dombois, K. W. Bridges, and H. L. Carson, eds. Island ecosystems: Biological organization in selected Hawaiian communities. HutchinsonRoss, Stroudsburg, $\mathrm{Pa}$.

174. Carson, H. L. 1981l. Microevolution in insular ecosystems. Pages 471-482 in D. Mueller-Dombois, K. W. Bridges, and H. L. Carson, eds. Island ecosystems: Biological organization in selected Hawaiian communities. HutchinsonRoss, Stroudsburg, $\mathrm{Pa}$.

175. Ashburner, M., H. L. Carson, and J. N. Thompson, JR., eds. 1981m. The genetics and biology of Drosophila. Vol. 3a. Academic Press, London.

176. Carson, H. L., and A. T. OhtA. $1981 n$ Origin of the genetic basis of colonizing ability. Pages $365-370$ in G. G. E. Scudder and J. L. Reveal, eds. Evolution today. Proc. 2nd Internat. Congr. Syst. Evol. Biol. Hunt Institute, Carnegie Mellon Univ., Pittsburgh, $\mathrm{Pa}$.
177. Carson, H. L., and T. OKada. 1982a. Drosophilidae of New Guinea. Pages 675-687 in J. L. Gressitt, ed. Biogeography of New Guinea. Junk, Amsterdam. Monogr. Biol. 42(2):675-687.

178. Carson, H. L., F. C. Val, C. M. Simon, and J. W. ArCHIE. 1982b. Morphometric evidence for incipient speciation in Drosophila silvestris from the island of Hawaii. Evolution 36: 132-140.

179. Carson, H. L. 1982c. Evolution of Drosophila on the newer Hawaiian volcanoes. Heredity 48:3-25.

180. Kaneshiro, K. Y., and H. L. Carson. 1982d. Selection experiments on mating behavior in Drosophila silvestris. Genetics 100:s34.

181. Giddings, L. V., and H. L. Carson. $1982 e$. Behavioral phylogeny of populations of Drosophila crucigera. Genetics 100:s26-27 (abstract).

182. Ashburner, M., H. L. Carson, and J. N. Thompson, Jr., eds. 1982f. The genetics and biology of Drosophila. Vol. 3b. Academic Press, London.

183. Carson, H. L., and J. S. Yoon. $1982 g$. Genetics and evolution of Hawaiian Drosophila. Pages 297-344 in M. Ashburner, H. L. Carson, and J. N. Thompson, Jr., eds. The genetics and biology of Drosophila. Vol. 3b. Academic Press, London.

184. Okada, T., and H. L. Carson. $1982 h$. Drosophilidae associated with flowers in Papua New Guinea III. Zingiberales. Kontyû 50(3): 396-410.

185. Carson, H. L., L. S. Chang, and T. W. LytTLE. 1982i. Decay of female sexual behavior under parthenogenesis. Science 218:68-70.

186. Carson, H. L. 1982j. Hawaii: Showcase of evolution. An introduction. Natural History 91(12): 76-78.

187. Carson, H. L. 1982k. Hawaii: Showcase of evolution. A cloudy future. Natural History 91(12): 72.

188. Carson, H. L., and L. T. Teramoto. 1982l. Bibliography of Hawaiian Drosophilidae. Dros. Inf. Serv. 58:215226.

189. Carson, H. L., C. B. Krimbas, and M. LoukAs. $1982 \mathrm{~m}$. Slime fluxes a 
larval niche of D. subobscura Col., Dros. Inf. Serv. 58:34-35.

190. Carson, H. L. $1982 n$. Speciation as a major reorganization of polygenic balances. Pages 411-433 in C. Barigozzi, ed. Mechanisms of speciation. Alan R. Liss, New York.

191. Carson, H. L. 1982o. Fluctuations in size of certain Drosophila populations in the Ola'a Tract, Hawaii Volcanoes National Park. Page 40 in Proc. 4th Conf. Nat. Sci. Hawaii Volcanoes National Park. Cooperative National Park Resources Study Unit. Dept. of Botany, Univ. of Hawaii, Honolulu (abstract).

192. OKada, T., and H. L. Carson. 1982p. Drosophilidae associated with flowers in Papua New Guinea IV. Araceae, Compositae, Convolvulaceae, Leguminosae, Malvaceae, Rubiaceae. Kontyû 50:511-526.

193. Carson, H. L., and T. OKada. $1982 q$. Drosophilidae associated with flowers in Papua New Guinea (Diptera: Drosophilidae). Entomol. Gen. 8:13-16.

194. Carson, H. L. 1983a. Genetical processes of speciation on high oceanic islands. Page 34 in Pac. Sci. Assoc. 15th Congr. Univ. of Otago, Dunedin, New Zealand. Vol. 1 (abstract). Royal Soc. New Zealand.

195. CARson, H. L. 1983b. Chromosomal sequences and interisland colonizations in Hawaiian Drosophila. Genetics 103: 465-482.

196. Hunt, J. A., and H. L. Carson. 1983c. Evolutionary relationships of four species of Hawaiian Drosophila as measured by DNA reassociation. Genetics 104:353-364.

197. Carson, H. L., and R. Lande. 1983d. Inheritance of a secondary sexual character in Drosophila silvestris. Genetics 104:s12 (abstract).

198. Ashburner, M., H. L. Carson, and J. N. ThOMPSON, JR., eds. 1983e. The genetics and biology of Drosophila. Vol. 3c. Academic Press, London.

199. Ashburner, M., and H. L. Carson. 1983f. A checklist of maps of polytene chromosomes of Drosophilids. Dros. Inf. Serv. 39: 148-151.

200. Carson, H. L. 1983g. The genetics of the founder effect. Pages 189-200 in C. M. Schonewald-Cox, S. M. Chambers, B. MacBryde, and L. Thomas, eds. Genetics and conservation. Benjamin/ Cummings, Menlo Park, Ca.

201. OKada, T., and H. L. Carson. $1983 h$. Drosophilidae from banana traps over an altitudinal transect in Papua New Guinea. I. Descriptions of new species and notes on newly recorded species. Internat. J. Entomol. 25:127-141.

202. Carson, H. L., and T. OKada. $1983 i$. Drosophilidae from banana traps over an altitudinal transect in Papua New Guinea. II. Frequency of species at eight collecting sites. Internat. J. Entomol. 25:142-151.

203. OKadA, T., and H. L. Carson. 1983j. The genus Sphaerogastrella Duda (Diptera, Drosophilidae) of Papua New Guinea. Kontyû 51:367-375.

204. Carson, H. L. 1983k. Artificial selection of a secondary sexual character in Drosophila silvestris of the island of Hawaii. Proc. 15th Internat. Congr. Genet. Oxford and IBH, New Delhi. Part II, p. 438 (abstract).

205. Carson, H. L., F. C. Val, and M. R. WheELER. 1983l. Drosophilidae of the Galapagos Islands, with descriptions of two new species. Internat. J. Entomol. 25:239-248.

206. Ashburner, M., H. L. Carson, and J. N. ThOMPSON, JR., eds. $1983 m$. The genetics and biology of Drosophila. Vol. 3d. Academic Press, London.

207. Carson, H. L., and W. B. HeED. $1983 n$. Methods of collecting Drosophila. Pages 1-28 in M. Ashburner, H. L. Carson, and J. N. Thompson, Jr., eds. The genetics and biology of Drosophila. Vol. 3d. Academic Press, London.

208. Carson, H. L. $1983 o$. Genetical processes of evolution on high oceanic islands. In I. W. B. Thornton, ed. Symp. Distr. Evol. Pac. Insects. GeoJournal 7:543-547.

209. Okada, T., and H. L. Carson. 1983p. 
The genera Phorticella Duda and Zaprionus Coquillett (Diptera, Drosophilidae) of the Oriental region and New Guinea. Kontyû 51:539-553.

210. Chang, L. S., and H. L. Carson. 1984a. Metaphase chromosome comparisons among five species of Hawaiian Drosophila. Genetics 107:s18-19.

211. Hunt, J. A., J. G. Bishop III, and H. L. CARSON. 1984b. Observation of a repetitive DNA element in five species of Hawaiian Drosophila. Genetics 107: s50.

212. Carson, H. L., and J. V. NeEL. 1984c. Harrison Dailey Stalker 1915-1982. Genetics 107:s138-140.

213. Carson, H. L., and L. T. Teramoto. 1984d. Artificial selection for a secondary sexual character in males of Drosophila silvestris from Hawaii. Proc. Nat. Acad. Sci. U.S. 81:3915-3917.

214. Herforth, R. S., H. L. Carson, and L. Chang. 1984e. A new arrival to the Hawaiian Islands: Drosophila cardini. Dros. Inf. Serv. 60:124.

215. Carson, H. L. 1984f. Sexual dimorphism and sexual selection in Hawaiian Drosophila. Page 51 in Proc. 5th Conf. Nat. Sci. Hawaii Volcanoes National Park. Cooperative National Park Resources Study Unit. Dept. of Botany, Univ. of Hawaii at Manoa, Honolulu (abstract).

216. Carson, H. L. $1984 g$. Genetics. Pages 193-194 in McGraw-Hill yearbook of science and technology. McGraw-Hill, New York.

217. Carson, H. L., and A. R. Templeton. 1984h. Genetic revolutions in relation to speciation phenomena: The founding of new populations. Ann. Rev. Ecol. Syst. 15:97-131.

218. Carson, H. L., and R. Lande. 1984i. Inheritance of a secondary sexual character in Drosophila silvestris. Proc. Nat. Acad. Sci. U.S. 81:6904-6907.

219. Carson, H. L. $1984 j$. Speciation and the founder effect on a new oceanic island. Pages 45-54 in F. J. Radovsky, P. H. Raven, and S. H. Sohmer, eds. Biogeography of the tropical Pacific. B. P. Bishop Museum, Honolulu.
220. Hunt, J. A., J. G. Bishop III, and H. L. CARSON. 1984k. Chromosomal mapping of a middle-repetitive DNA sequence in a cluster of five species of Hawaiian Drosophila. Proc. Nat. Acad. Sci. U.S. 81:7146-7150.

221. Crews, D., L. T. Teramoto, and H. L. CARSON. 1985a. Behavioral facilitation of reproduction in sexual and parthenogenetic Drosophila. Science 277:7778.

222. Carson, H. L. 1985b. Genetic variation in a courtship-related male character in Drosophila silvestris from a single Hawaiian locality. Evolution 39:678686.

223. Chang, L. S., and H. L. Carson. $1985 c$. Metaphase karyotype identity in four homosequential Drosophila species from Hawaii. Can. J. Genet. Cytol. 27: 308-311.

224. Takenaka, J. H., H. L. Carson, and D. CREws. 1985d. Active courtship behavior and copulatory success by sterile XO males of Drosophila mercatorum. Genetics 110:s101 (abstract).

225. Titus, E. A., H. L. Carson, and R. G. WisOTZKEY. 1985e. Another new arrival to the Hawaiian Islands: Drosophila bryani Malloch. Dros. Inf. Serv. 61:171.

226. Carson, H. L. $1985 f$. Evolution of fish species flocks, edited by A. A. Echelle and I. Kornfield, a review. Quart. Rev. Biol. 60:347-348.

227. Carson, H. L. $1985 \mathrm{~g}$. Unification of speciation theory in plants and animals. Syst. Bot. 10:380-390.

228. Carson, H. L., C. B. Krimbas, and M. Loukas. 1985h. Slime fluxes, a larval niche of Drosophila subobscura Col. Congr. Internat. Zoogeogr. Ecol. Grèce Reg. Avois. Biologia GalloHellenica 10:319-321.

229. Carson, H. L. 1985i. Genetic microdifferentiation due to sexual selection in Drosophila and man. Pages 1-14 in Y. R. Ahuja and J. V. Neel, eds. Genetic microdifferentiation in human and other animal populations. Indian Anthropol. Assoc. Univ. of Delhi, New Delhi. 
230. Ashburner, M., H. L. Carson, and J. N. ThOMPSON, JR., eds. 1986a. The genetics and biology of Drosophila. Vol. 3e. Academic Press, London.

231. CARsON, H. L. 1986b. Inversion heterozygosity is disproportionately high among copulating males of Drosophila silvestris. Genetics 113:s39.

232. Wisotzkey, R. G., and H. L. Carson. 1986c. Sperm predominance in Drosophila silvestris. Genetics 113:s46 (abstract).

233. Carson, H. L. 1986d. Sexual selection and speciation. Pages 381-409 in S. Karlin and E. Nevo, eds. Evolutionary processes and theory. Academic Press, London.

234. Carson, H. L., K. Kaneshiro and W. P. Mull. 1986e. Natural hybridization between two species of Hawaiian Drosophila. Page 35 in Abstr. 1st Internat. Congr. Dipterol. Hungarian Acad. of Sci., Budapest.

235. Carson, H. L. 1986f. Drosophila popu- lations in the Ola'a Tract, Hawaii Volcanoes National Park, 1971-1986. Pages 3-9 in Proc. 6th Conf. Nat. Sci. Hawaii Volcanoes National Park. Cooperative National Park Resources Study Unit. Dept. of Botany, Univ. of Hawaii at Manoa, Honolulu.

236. Carson, H. L. 1986g. The origin of species. Pages 117-121 in R. J. Berry and A. Hallam, eds. The Collins encyclopedia of animal evolution. Collins, London.

237. Carson, H. L. 1986h. Change in isolation: Speciation in the Hawaiian Island. Pages 124-125 in R. J. Berry and A. Hallam, eds. The Collins encyclopedia of animal evolution. Collins, London.

238. Carson, H. L. 1986i. Patterns of inheritance. Amer. Zool. 26: 797-809.

239. Carson, H. L. 1987. Population genetics, evolutionary rates, and neoDarwinism. Pages 209-217 in K. S. W. Campbell and M. F. Day, eds. Rates of evolution. Allen and Unwin, London. 